\title{
PENGALAMAN PARAMADINA SEBAGAI RUMAH PENGETAHUAN BERBASIS NILAI-NILAI KETUHANAN, TRADISI HIKMAH DAN ILMU PENGETAHUAN
}

\author{
Muhammad Sabri \\ Universitas Islam Negeri Alauddin Makassar, Indonesia \\ E-mail: mohdsabriar@yahoo.co.id \\ Muh. Ikhsan \\ Institut Agama Islam Negeri Kendari, Indonesia \\ E-mail: ichank_ar@yahoo.co.id \\ Ismail Suardi Wekke \\ Sekolah Tinggi Agama Islam Negeri Sorong, Indonesia \\ E-mail: iswekke@gmail.com
}

\begin{abstract}
This article describes Paramadina University, a higher educational institution in Indonesia, which cannot be separated from its leader as well as the founder of its initial idea, i.e. Nurcholish Madjid. The existence of Paramadina University is, therefore, more closely related to the establishment of Nurcholish Madjid's genial ideas who attempted to link the idea of Islam-Modernity-Indonesia. Since its initial inauguration in 1994, Paramadina University has carried out basic insights aimed at building a scientific society based on divine values and wisdom of humanity. It also encourages the values of pioneering souls to break through the borders of knowledge. Employing qualitative approach, this article aims at further analyzing the model of modern religious tradition developed by Paramadina University. The study affirms central position and role played by this higher educational institution both in Indonesia and the Islamic world in general. This centrality appears, especially, when we link the ideas of Islamic universalism, spatial-temporal of indonesianess, along with responses toward the life of the contemporary society which seems to be not only complex but also moves quickly escorting the breath of the age.
\end{abstract}

Keywords: Tradition of wisdom; knowledge; Paramadina University. 


\section{Pendahuluan}

Sekitar 30 tahun silam, Aswab Mahasin pernah mengatakan bahwa "Sebuah angkatan baru sementara merambah citra Islam yang inklusif, yang lebih pradah dan membiarkan jalan menuju penyempurnaan-udkhulū fì al-silm käffah-ditempuh dalam proses kesadaran tanpa hardikan dan hura-hura. Dengan begitu, sebenarnya angkatan ini sedang berusaha keluar dari kungkungan nasib sebagai minoritas politik menuju mayoritas budaya yang lebih besar. ${ }^{1}$

Tidak sedikit kalangan menilai jika esai di atas menyiratkan optimisme keberagamaan di Indonesia. Kutipan tersebut mencoba mengilustrasikan "bayang-bayang" angkatan baru Islam Indonesia yang oleh Mahasin bahkan telah menyerukan marbaban (selamat datang) kepada angkatan baru itu. Satu angkatan, bagi Aswab, tidak lahir untuk menyudahi. Dengan puitis Aswab menutup esainya: "laksana bait-bait azan dari menara, mereka justru datang untuk memulai".

Angkatan baru yang dilansir Aswab tak lain dari fenomena yang belakangan ini ditujukan kepada mereka yang disebut sebagai "kelompok pembaruan pemikiran Islam" di Indonesia. Gerakan ini muncul lebih merupakan respons Islam terhadap gagasan modernisasi di Indonesia. Atau dalam maknanya yang paling sederhana, fenomena tersebut dapat dipandang sebagai respons intelektual kaum Muslim terhadap situasi sosio-historis yang melingkari kehidupan bangsa Indonesia saat itu.

Karena itu, tidak mengherankan jika pada dekade akhir 1960-an pemikiran Islam di Indonesia terfokus pada tema-tema modernisasi serta sejumlah implikasi yang ditimbulkannya. Dalam ungkapan Kuntowijoyo, pada saat itu telah berlangsung pergeseran orientasi keislaman dari periode sejarah Islam yang bersifat mitos dan ideologis, memasuki periode ide atau ilmu. ${ }^{3}$ Semenjak itu sesungguhnya telah terjadi apa yang disebut Nurcholish Madjid sebagai "gelombang intelektualisme Islam" ${ }^{4}$ di Indonesia. Pada saat itu, anak-anak Muslim,

\footnotetext{
${ }^{1}$ Aswab Mahasin, “Marhaban”, Prisma, No. Ekstra (1984), 2.

2 Ibid.

${ }^{3}$ Lihat, Pelita, 28 Juli 1989.

${ }^{4}$ Secara teknis, istilah "Gelombang Intelektualisme Islam I di Indonesia" untuk pertama kali dikenalkan Cak Nur-demikian panggilan populer Nurcholish Madjid_-dalam salah satu diskusi di KKA Paramadina, "Kultur Politik Orde Baru: Ketegangan antara Kultur Pesisir dan Kultur Pedalaman”, pada 7 September 1996. Istilah itu sesungguhnya ingin memperlihatkan satu fenomena dari kebangkitan
} 
khususnya yang meraih kesarjanaan di sejumlah perguruan tinggi, kian sadar dengan permasalahan yang dihadapi bangsanya. Pikiran-pikiran Islam yang cerdas, solutif, dan modern dengan demikian menjadi sebuah keniscayaan. Itu pula sebabnya mengapa semenjak tahun 1970-an hingga dekade awal 1980-an, gerakan pembaruan pemikiran Islam di Indonesia kian menemukan momentumnya. ${ }^{5}$

umat Islam Indonesia yang telah menanam "investasi" di bidang pendidikan sejak Kabinet Natsir (1950). Sudah semenjak awal dasawarsa 1960-an putra-putri kaum "santri" menyerbu berbagai perguruan tinggi dan menjadi anggota masyarakat akademik (civitas akademika) yang besar dan aktif. Karena itu mulai awal dasawarsa 1970-an umat Islam menyaksikan putra-putri mereka tamat pendidikan tingkat tinggi atau universitas dan menjadi sarjana. Fenomena ini oleh para peneliti sosial di Indonesia disebut pula sebagai boom sarjana Islam. Dari aktivitas serta gagasan pemikiran yang muncul sebagai respons mereka terutama terhadap ide-ide modernitas itulah, sehingga fenomena ini pun disebut sebagai "gelombang intelektualisme Islam I di Indonesia."

5 Pertumbuhan dan geliat perkembangan pemikiran keislaman "baru" di Indonesia, merupakan lahan kajian menarik para sarjana. Antara lain karena beberapa gagasan segar dan sekaligus menyulut polemik, gerakan pembaruan pemikiran Islam pun tergolong fenomena yang memperoleh publikasi besar-besaran dari media massa khususnya mingguan Tempo dan Prisma. Beberapa karya tulis serius mengenai gerakan pembaruan pemikiran tersebut kemudian lahir dalam bentuk buku, disertasi, maupun artikel. Sebut saja diantaranya B.J. Boland, The Struggle of Islam in Modern Indonesia (The Hague: Martinus Nijhoff, 1982). Bandingkan B.J. Boland, "Discussion on Islam in Indonesia Today," Studies in Islam: A Symposium on Islamic Studies, Amsterdam, 18-19 Oktober 1973 (Amsterdam: North Holland Publishing Company, 1974), 37-50. Karya-karya lain: R. William Liddle, "Changing Political Culture: Three Indonesian Cases," kertas kerja pada Konferensi tentang Indonesia Modern, Flinders University, Adelaide, South Australia, September 1991; Douglas Edward Ramage, "Ideological Discourse in the Indonesian New Order: State Ideology and the Belief of an Elite, 1985-1993" (Disertasi--International Studies, Department of Government and International Studies, University of South California, 1993); M. Rusli Karim, "Responsi Cendekiawan Muslim terhadap Tuntutan Masyarakat Modern di Indonesia", dalam M. Amin Rais (ed.), Islam di Indonesia: Suatu Ikbtiar Mengaca Diri (Jakarta: Rajawali, 1986), 237-265; Moeslim Abdurrahman, "Bagaimana Indonesia Dibaca Pemikir Islam: Sebuah Resensi Pemikiran," dalam Muntaha Azhari dan Abdul Muni Saleh (eds.), Indonesia Menatap Masa Depan (Jakarta: Guna Aksara, 1989); Gregory J. Barton, "The Emergence of Neo-Modernism; a Progressive, Liberal, Movement of Islamic Thought in Indonesia: A Textual Study Examining the Writing of Nurcholish Madjid, Djohan Effendi, Ahmad Wahib and Abdurrahman Wahid 1968-1980" (Disertasi-Department of Asian Languages and Studies Monash University, 1995; Budhy Munawar-Rahman, "Dari Tahapan Moral ke Periode Sejarah Pemikiran NeoModernisme Islam di Indonesia," Ulumul Qur'an, Vol. 6, No. 3 (1995); dan M. Syafi'i 
Artikel ini mencoba memotret bagaimana posisi Paramadina sebagai sebuah institusi kajian dan pendidikan dalam kaitannya dengan fenomena kegairahan intelektualisme Islam di Indonesia. Untuk mengurai lebih detail, sedikitnya ada dua pertanyaan mendasar yang mesti dijawab: (1) bagaimana situasi sosio-historis yang mendorong kelahiran Paramadina; dan (2) seberapa jauh peran Paramadina dalam gerakan intelektualisme Islam di tanah air yang belakangan kian memperlihatkan intensitasnya.

\section{Fenomena Sarjana Islam, Lahirnya Lokomotif Pembaruan}

Seperti disebutkan sebelumnya, salah satu pendorong munculnya gagasan pembaruan pemikiran Islam di tanah air pada dekade awal 1970-an adalah ide tentang modernitas. Dengan begitu, yang menjadi diskursus paling kental saat itu adalah apa makna persis modernisasi bagi umat Islam. Sejumlah sarjana Muslim lalu mencoba merumuskan makna modernitas secara lebih dalam, sembari melihat kemungkinan pemanfaatan wacana ini bagi umat Islam dalam menatap masa depan bangsanya.

Nurcholish Madjid misalnya-sebagai salah seorang tokoh terpenting dalam gerakan pembaruan pemikiran Islam saat ituberpandangan jika "modernisasi berarti berpikir dan bekerja sesuai dengan hukum-hukum alam. Karena itu, modernisasi adalah suatu keharusan bahkan suatu kewajiban mutlak... Modernisasi merupakan perintah dan ajaran Tuhan."

Pikiran yang berasal dari masa ketika ia menjadi Ketua Umum PB HMI 1966-1969 itu, bukanlah suatu "rasionalisme" tetapi-

Anwar, Pemikiran dan Aksi Islam Indonesia: Sebuah Kajian Politik tentang Cendekiawan Muslim Orde Baru (Jakarta: Paramadina, 1995).

${ }^{6}$ Nurcholish Madjid, "Modernisasi ialah Rasionalisasi Bukan Westernisasi" dalam Islam Kemodernan dan Keindonesiaan (Bandung: Mizan, 1987), 175. Dalam artikel ini, Cak Nur merumuskan modernisasi sebagai rasionalisasi. Pengertian Cak Nur tentang "modernisasi sebagai rasionalisasi," pada saat itu kurang lebih tak berbeda dengan misalnya Harun Nasution, yang dikenal dengan "teologi rasionalnya" (neoMu'tazilah). Tapi dengan kata "rasional" di sini, Cak Nur tak boleh dikaitkan dengan Mu'tazilah, karena itu hanyalah salah satu bentuk saja dari kemungkinan teologi rasional. Pengaitan Nurcholish dengan Mu'tazilah akan membuat salah paham terhadap pengertiannya mengenai "rasionalnya" itu. Rasional seperti yang dimaksud Nurcholish, pada hakikatnya berkaitan dengan "penerapan ilmu pengetahuan," yang kemudian berarti penerjemahan al-isläm dalam term ilmu-yang menurutnya merupakan suatu keharusan, malah kewajiban mutlak, karena merupakan proses penemuan kebenaran-kebenaran mencapai Kebenaran Mutlak, yaitu Allah. 
meminjam istilah Karl Popper, "rasional-(isme) yang kritis." Maksudnya, ia menganggap Kebenaran adalah sesuatu yang hanya dapat dicapai dalam proses. Kebenaran (dengan $\mathrm{K}$ besar) adalah tujuan, yang boleh dikatakan karena keterbatasan manusia tak akan dapat dicapai secara penuh, tapi harus terus menerus dicari. Pencarian (dan "penyerahan diri") yang terus menerus tentang Kebenaran (alisläm) itulah yang disebut sebagai "sikap yang modern."

Disadari atau tidak, ketika Nurcholish dan kawan-kawan melontarkan gagasan pembaruan pemikiran Islam di tahun 1970-an itu, yang terjadi sebenarnya adalah sebuah respons intelektual terhadap kondisi sosio-politik umat Islam yang berada pada posisi periferal. Sebab, seperti diketahui, pada saat yang bersamaan, dicetuskannya satu keputusan penting oleh pemerintah Orde Baru mengenai dimulainya "era pembangunan" (developmentalism) yang berparadigma modernis. Kebijakan ini pada urutannya sangat menguntungkan 'kelas menengah kota' yang tergolong dalam apa yang disebut Syafi'i Anwar sebagai secular modernizing intellectual.

Sementara itu kalangan Islam modernis, terutama tokoh seniornya, justru bersikap ragu bahkan apologi dengan menolak modernisasi karena dinilai sebagai westernisasi, dan karena itu pula sekularisasi. Sikap seperti inilah yang tidak menguntungkan. Akibatnya, Islam dituduh sementara pihak sebagai tradisional, antimodernisasi, anti-pembangunan dan konyolnya: anti--Pancasila!

Kondisi itulah yang kemudian "memaksa" Nurcholish dan kawankawan melontarkan gagasan pembaruannya. Lewat pidatonya yang menyulut polemik dan mengundang badai kritik, "Keharusan Pembaruan Pemikiran Islam dan Masalah Integrasi Umat," Nurcholish tiba pada satu kesimpulan: kaum Muslim Indonesia sekarang ini telah mengalami kejumudan kembali dalam pengembangan ajaran-ajaran Islam, dan kehilangan psychological striking force atau daya dobrak psikologis dalam perjuangannya. ${ }^{8}$

7 M. Syafi'i Anwar, "Sosiologi Pembaruan Pemikiran Islam Nurcholish Madjid" Ulumul Qur'an, Vol. 4, No. 1 (1993), 50. Kelompok ini jelas sangat diuntungkan oleh kebijakan Orde Baru tentang developmentalism, sebab di samping mereka secara kultur akademik "lebih siap" juga terutama karena sikap pragmatisme yang dianutnya. Karena itu, kelompok ini boleh dibilang tidak mengalami hambatan psikologis atau pun ideologis terhadap gemuruh modernisasi yang justru menjadi paradigma dominan "pembangunan" saat itu.

${ }^{8}$ Madjid, Islam Kemodernan, 204. Tulisan ini berasal dari kertas kerja yang dibacakan Nurcholish pada silaturrahim antara para aktivis, anggota dan keluarga besar empat 
Untuk kasus di atas, Nurcholish mengajukan dua pilihan: pembaruan, dengan risiko merugikan integrasi umat; atau tetap mempertahankan integrasi dengan akibat mentolerir kebekuan pemikiran dan hilangnya kekuatan moral. Nurcholish sendiri, akhirnya, memilih yang pertama: pembaruan. Dalam retrospeksi, hemat saya, pilihan pada pembaruan dipandang sebagai pendekatan yang paling rasional dan realistik dalam merespons modernisasi; ketimbang persatuan umat yang belum jelas arah dan tujuannya. Karena modernisasi itu sendiri berkaitan dengan masalah persiapan mental, Nurcholish dan kawan-kawan seperti M. Dawam Rahardjo, Ekky Syahruddin, Utomo Danandjaya, Usep Fathuddin, dan lainlain-yang sebagian besarnya kelak bersama Nurcholish mendirikan Paramadina - tidak mengadvokasi secara langsung terhadap strategi pembangunan. Perhatian mereka justru lebih bersifat inward looking atau tertuju kepada persiapan mental umat Islam sendiri, dan tidak berbicara atau memberikan penilaian terhadap pembangunan. Dengan begitu, dapat dikatakan, salah satu ciri menonjol pembaruan Nurcholish dan kawan-kawannya pada tahun 1970-an adalah introspektif atau kritis ke dalam, terkadang malah menggunakan metode shock teraphy.

Tak pelak, gagasan pembaruan Nurcholish dan kawan-kawannya mendapat respons dan kritik tajam dari sejumlah tokoh Islam saat itu. Polemik lalu meledak, dan tak jarang dibungkus oleh aroma kemarahan yang menyala-nyala. ${ }^{10}$ Dinamika pemikiran itu berlangsung

organisasi: Persami, HMI, GPI, dan PII, yang diselenggarakan oleh PII Cabang Jakarta, di Jakarta, 3 Januari 1970.

9 Ungkapan-ungkapan Nurcholish seperti "sekularisasi”, “desakralisasi”, "demitologisasi", "tiada tuhan selain Tuhan", "Pancasila sebagai kalimat sawā", "melanggar bukum keseimbangan adalah dosa kosmik", "keniscayaan penumbuhan etos kerja" dan lain-lain, adalah salah satu bentuk metode shock teraphy yang dilancarkannya. Hal ini dilakukan Nurcholish antara lain untuk mempertanyakan dan menggugah kembali persepsi kaum Muslim Indonesia terhadap konsep-konsep teologi, politik dan kemasyarakatan mereka terutama saat diperhadapkan dengan gelombang perubahan sosial yang sangat dahsyat dan kecenderungan perkembangan masa depan, sebagai bagian dari dinamika modernisasi.

${ }^{10}$ Karena kesimpangsiuran pengertian istilah yang dikenalkan Nurcholish, maka tak kurang dari seratus tulisan pada tahun 1970-an telah terbit, menyusul gagasangagasan kontroversinya itu melalui surat kabar Abadi, Kompas, Mercu Suar, Indonesia Raya, majalah Panji Masyarakat, Angkatan Baru, Mimbar Demokrasi, Forum, Tempo, dan lain-lain. Reaksi emosional berkaitan dengan kerumitan soal terminologi itu muncul dalam pernyataan, "sekularisasi sebagai jembatan ke arah komunisme," 
hingga dasawarsa 1980an, dan sedikit menyurut terutama sesaat Nurcholish melanjutkan studi doktoralnya ke University of Chicago di Amerika Serikat, 1978-1984.

Meski demikian, tidak dengan sendirinya berarti kontroversi di sekitar pembaruan pemikiran Islam lalu hilang. Tahun-tahun itu, adalah Harun Nasution yang menjadi kontroversi, menyusul gagasannya membangun suatu teologi Islam yang rasional atas dasar pemikiran neo-Mu'tazilah Muhammad 'Abduh. Kontroversi Harun, berada di sekitar usahanya mengenalkan teologi $\mathrm{Mu}^{\text {'tazilah, termasuk }}$ cara mengajarnya yang sangat liberal. Usaha Harun itu, telah "memaksa" intelektual gaek Prof. Rasjidi mengoreksi buku Harun, Islam Ditinjau dari Berbagai Aspeknya. ${ }^{11}$

Menjelang Nurcholish kembali (sekira tahun 1982-1983), di Jakarta sekelompok alumni IAIN Syarif Hidayatullah yang dipengaruhi rasionalisme Harun Nasution-berusia 30-an dan menyebut dirinya sebagai "pembaru"-membentuk sebuah circle yang bernama Kelompok Studi Agama "Proklamasi." Kelahiran kelompok ini diinspirasi oleh Djohan Effendi, dengan Mansour Fakih dan Jimly Ashiddieqy sebagai koordinator pelaksananya. Nama-nama anak muda seperti Fachry Ali, Azyumardi Azra, Achmad Zakiy Siradj, Komaruddin Hidayat, Hadimulyo, M. Syafi'i Anwar-untuk sekadar menyebut beberapa di antaranya-terlibat dalam diskusi-diskusi di

atau "komunisme adalah anak sekularisme," dan sebagainya. Jika dirumuskan dalam perdebatan sekarang ini, tak sedikit orang awam menganggap, pemikiran Nurcholish cenderung sekuler, Barat-oriented, terjebak pemikiran Yahudi, berorientasi elitis, memberi angin kepada Kristenisasi, terjebak pada strategi Ali Murtopo, keterangannya membuat umat bingung, teologinya mengganggu kemapanan iman dan lembaga keagamaan, banyak pengertian-pengertiannya yang kacau, counterproductive terhadap perjuangan umat, ikut merangsang reaksi fundamentalisme, menimbulkan skeptisisme terhadap agama, bahkan ada yang menuduh jika Nurcholish telah menyimpang dari ajaran Islam. Penjelasan lebih jauh, lihat Budhy Munawar-Rachman, "Berbagai Respon atas Gagasan Pembaruan," Ulumul Qur'an, Vol. 4, No. 1 (1993), 54-58.

11 Buku Rasjidi dimaksud adalah Koreksi terhadap Dr. Harun Nasution tentang Islam Ditinjau dari Berbagai Aspeknya. Sementara itu, koreksi Prof. Rasjidi yang lain, ditulis menyangkut buku harian Ahmad Wahib-belakangan terbit dengan judul Pergolakan Pemikiran Islam: Catatan Harian Abmad Wabib (Jakarta: LP3ES, 1985), yang diedit oleh Ismed Natsir dan diberi kata pengantar oleh "karibnya" A. Mukti Ali dan Djohan Effendi-yang dianggapnya berbahaya. Koreksi serupa pernah dilakukan Rasjidi terhadap Nurcholish Madjid dengan judul, Sekularisme dalam Persoalan Lagi: Suatu Koreksi atas Tulisan Drs. Nurcholish Madjid (Jakarta: Yayasan Bangkit, 1972) dan Suatu Koreksi Lagi bagi Drs. Nurcholish Madjid (Jakarta: DDII, 1973). 
kelompok ini. Sebagian di antara mereka bekerja di LP3ES, LSP atau PPA sebagai social worker\%:

Mereka mendiskusikan gagasan-gagasan pembaruan yang fundamental terhadap pembangunan di Indonesia. Maka soal-soal sekularisasi, rasionalisasi teologi, gagasan-gagasan progresif, liberalisasi pemikiran, penolakan terhadap finalitas pemikiran keagamaan, dan sebagainya kembali menjadi tema-tema diskusi mereka. Secara simplistis dapat dikatakan, mereka berusaha memberi substansi atas gagasan-gagasan pembaruan yang telah dirintis Nurcholish Madjid dan Harun Nasution. Karena itu, rencana kedatangan kembali Nurcholish ke tanah air setelah tujuh tahun di rantau dan di antara rimba beton di Chicago, sangat memberi spirit dan kekuatan pada kelompok ini untuk terus memikirkan reaktualisasi Islam. Apalagi belakangan Munawir Syadzali dan Abdurrahman Wahid kian "mematangkan" dan juga tak sedikit memberi substansi pemikiran pembaruan dalam 10 tahun terakhir. ${ }^{12}$

Setelah kembali, Nurcholish mencoba mengaktualkan kembali gagasan-gagasan pembaruan 1970-an itu dengan substansi yang lebih mendalam. Tulisan pertamanya yang sangat genial, terbit beberapa saat sebelum kedatangannya, yaitu wawancara tertulis yang diberi judul, "Cita-cita Politik Kita". 13 Dalam tulisan tersebut Nurcholish memberi substansi atas gagasan sekularisasi politiknya yang dulu dirumuskan dalam jargon Islam Yes, Partai Islam No. Dalam tulisan inilah Nurcholish terlihat menggunakan perspektif neo-modernisme dalam melihat persoalan kemodernan Islam. Karena itu, bagi Cak Nur, dalam membangun kemodernan Islam di masa sekarang, "yang paling diperlukan adalah pengkajian yang lebih sistematis akan

\footnotetext{
12 Kebangkitan kaum cendekiawan Muslim_sebagai salah satu efek positif boom sarjana Muslim tahun 1970-an-dalam merespons dinamika modernisasi, juga muncul dari kalangan Islam "revivalis" kota, yang basisnya adalah di perguruan tinggi umum seperti UI, IPB, UNPAD, ITB, dan UGM. Tokoh-tokoh Islam seperti 'Imaduddin 'Abdulrahim, Jalaluddin Rakhmat, A.M. Saefuddin, dan Amin Rais (waktu itu) adalah figur mereka yang acapkali dikontraskan dengan Nurcholish Madjid dan Harun Nasution. Tapi belakangan figur-figur dimaksud, berkat terciptanya meeting of mind di antara mereka, menyebabkan satu sama lainnya melahirkan sikap "saling memahami" kendati tanpa kehilangan kritisisme masingmasing. Konfergensi sejumlah corak pemikiran di antara figur-figur tersebut menciptakan fenomena yang tipikal, sehingga oleh sementara peneliti sosial memandang fenomena itu sebagai bangkitnya "neo-santri" di Indonesia.

13 Hasil wawancara tertulis itu belakangan termuat dalam Aspirasi Umat Islam di Indonesia (Jakarta: LEKNAS, 1985), 1-36.
} 
sumber-sumber ajaran Islam, penghargaan yang lebih baik, namun tetap kritis terhadap warisan kultural umat, dan pemahaman yang lebih tepat akan tuntutan zaman yang semakin berkembang secara cepat." ${ }^{\prime 14}$

Dalam tulisan tersebut ia menyebutkan tentang peranan Islam dalam membangun Indonesia modern. Intinya: Islam adalah agama kemanusiaan. Karena itu, secara hakiki watak Islam bersifat inklusif. Maksudnya, pikiran (sistem Islam) yang dikehendaki ialah sistem yang menguntungkan semua orang, karena cita-cita Islam identik dengan cita-cita kemanusiaan. Gagasan Nurcholish kemudian kian berkembang dan matang, khususnya setelah ia dan kawan-kawannya kelak mendirikan Yayasan Wakaf Paramadina, pada Juli 1986.

Bila ditelaah lebih jauh, perkembangan sosial-politik yang terjadi pada dekade 1980-an, sesungguhnya lebih merupakan kelanjutan dari pada dekade 1970-an. Namun demikian, dekade 1980-an ditandai dengan perubahan sosial-politik dan ekonomi yang mempunyai dampak sangat luas terhadap perkembangan pemikiran politik umat Islam di tanah air. Perubahan yang penting dalam dekade 1980-an adalah semakin menguatnya posisi negara dalam percaturan politik dan ekonomi. Menguatnya posisi negara ini dimungkinkan berkat ragam kemajuan pembangunan yang, meskipun relatif, mempunyai dampak luas bagi terciptanya perubahan sosial (social changes) pada masyarakat Indonesia, termasuk umat Islam.

Di bidang politik, dalam usahanya untuk kian memperkuat posisi negara, Orde Baru pada awal dekade 1980-an memperlihatkan langkah-langkah yang sangat "ofensif," khususnya di bidang penataan ideologi. Kebijakan politik yang ofensif itu secara nyata tampak pada usaha pemerintah Soeharto yang menghendaki penerapan Pancasila sebagai satu-satunya asas kekuatan sosial-politik (Orsospol) dan organisasi kemasyarakatan (Ormas). Kebijakan ini merupakan kulminasi dari serangkaian kebijakan politik yang dilakukan pemerintah Orde Baru dalam kurun waktu 1966-1985.

Bermula dari pidato kenegaraan presiden Soeharto di hadapan Sidang Paripurna DPR-RI pada 16 Agustus 1982, gagasan penetapan Pancasila sebagai satu-satunya asas bagi Orsospol dan Ormas terus menggelinding dan memperoleh legitimasi lewat Ketetapan Sidang Umum MPR tahun 1983. Gagasan ini sesungguhnya merupakan "paket" yang tertunda dari upaya pemerintah melakukan pembenahan

14 Ibid., 5. 
sistem politik yang menekankan pentingnya stabilitas politik dan keamanan (security approach), antara lain dengan menghapuskan "asas ciri" yang melekat pada kedua Orsospol: PPP dan PDI.

Kendati pada awalnya kebijakan itu mendapat kritik dan kecaman yang tajam dari tokoh-tokoh politik dan Ormas baik dari kalangan Islam maupun lainnya, tapi tak lama setelah itu mereka seakan-akan berlomba menerima Pancasila sebagai satu-satunya asas, sekalipun dengan berbagai improvisasi politik. Sikap responsif kalangan Ormas Islam itu semakin mantap ketika ada jaminan dari Presiden Soeharto yang disampaikan dalam pembukaan Muktamar Muhammadiyah di Solo tahun 1985, yang menyatakan bahwa, "Pancasila bukan agama dan agama tidak akan di-Pancasila-kan." ${ }^{\text {"16 }}$ Ditambah lagi dengan fakta yang cukup kuat bahwa pemerintah Orde Baru menaruh perhatian serius terhadap peningkatan kualitas hidup dan kesejahteraan sosial lewat serangkaian program-program pembangunan di bidang agama.

15 Kebijakan pemerintah tentang keharusan menjadikan Pancasila sebagai satusatunya asas Orsospol maupun Ormas, belakangan melahirkan polemik berkepanjangan. Meskipun sebenarnya, kebijakan ini telah ditetapkan melalui UU No. 3 Tahun 1975 tentang Parpol dan Golkar. Tapi UU tersebut masih memberi "peluang" kepada parpol untuk mencantumkan asas cirinya masing-masing selain menetapkan Pancasila sebagai asas partai. Karena itu, PPP misalnya masih mencantumkan asas ciri berupa "asas Islam" dan PDI dengan "asas Demokrasi Indonesia dan Keadilan Sosial". Namun dalam pandangan pemerintah kemudian, ternyata "asas ciri” yang masih melekat pada Orsospol bersangkutan justru menjadi sumber konflik dan pemicu sejumlah kerusuhan seperti yang terjadi saat kampanye pemilu. Karena itu, demi persatuan dan kesatuan nasional, pemerintah merasa berkepentingan meredam fanatisme ideologi dan golongan dengan cara menetapkan Pancasila sebagai satu-satunya asas bagi Orsospol dan Ormas tersebut.

16 Lihat M. Sirajuddin Sjamsuddin, "Religion and Politics in Islam: the Case of Muhammadiyah in Indonesia's New Order" (Disertasi--University of California Los Angeles, 1991), 249. Meski demikian, tidak dengan sendirinya berarti jika penetapan Pancasila sebagai satu-satunya asas Orsospol dan Ormas oleh pemerintah, diterima seluruh organisasi di Indonesia. Terutama di kalangan Ormas, perdebatan mengenai "asas tunggal"- demikian istilah ini secara pejoratif beredar di kalangan Ormasmasih tetap berlangsung, hingga pada akhirnya terjadi friksi bahkan mengakibatkan "hapusnya" eksistensi sebuah Ormas. Sebut saja misalnya HMI, PII dan Generasi Muda Marhaen. Untuk yang pertama, setelah melalui pergulatan cukup panjangbaik lewat Rapat Pimpinan HMI, Sidang MPK, maupun Kongres-akhirnya menemukan jalan buntu. Akibatnya organisasi ini terpecah dua: HMI yang menerima Pancasila dan HMI MPO yang menolak tegas Pancasila sebagai asasnya. Sementara dua Ormas yang disebutkan terakhir, secara tegas menolak pencantuman Pancasila sebagai asas Ormas mereka, sehingga oleh pemerintah melalui UU No. 8 tahun 1985, keduanya dianggap "menyatakan diri bubar." 
Dengan menyatakan bahwa "Pancasila bukan agama dan agama tidak akan di-Pancasila-kan," Soeharto sesungguhnya telah melakukan rasionalisasi terhadap ideologi negara (rationalization of state ideology), sehingga mengakhiri ketegangan konseptual yang bersumber dari kekhawatiran adanya mitos penyejajaran (juxtaposition) antara agama dan Pancasila. Pada saat yang sama, rasionalisasi terhadap Pancasila telah mereduksi kekuatan-kekuatan politik yang melakukan ideologisasi dan politisasi agama sebagai "alternatif" terhadap ideologi negara. Akibatnya, seperti digambarkan Syafi'i Anwar, dalam dekade 1980-an terjadi kemerosotan pengaruh "kaum ideologis" Islam. Hal itu terlihat dengan ketidakberhasilan, jika bukannya kegagalan, dari usaha sementara tokoh dan aktivis Islam yang menyerukan penolakan terhadap penerapan Pancasila sebagai sebagai satu-satunya asas bagi organisasi politik dan organisasi massa. ${ }^{17}$

Sesungguhnya, kemerosotan pengaruh kaum "ideologis" Islam itu bukannya tanpa penyebab. Sejumlah argumen dapat dikemukakan di sini. Pertama, tidak saja karena penerapan Pancasila sebagai satusatunya asas, tetapi juga adanya suatu rangkaian kemunduran-kalau tak hendak disebut kekalahan-di kalangan "politik Islam" dan "Islam politik" dalam Orde Baru. Sejumlah pengamat mengatakan, kemunduran itu, terutama sekali disebabkan oleh rekayasa dan ofensif politik Orde Baru sejak menggenggam kekuasaan. Kebijakan politik Orde Baru seperti restruksturisasi politik, depolitisasi, politik massa mengambang, dan sebagainya seringkali dianggap sebagai variabel sangat menentukan dalam menganalisis kemunduran "politik Islam" dan "Islam politik".

Kedua, jika kita memperhatikan perkembangan politik dalam dekade 1980-an, tampak bahwa di kalangan umat Islam sendiri telah terjadi pergeseran paradigma pemikiran (shifting paradigm) yang cukup signifikan. Karena itu, kegagalan yang berulang-ulang dalam kancah politik Orde Baru, pembangunan bidang agama yang secara faktual barmanfaat bagi umat Islam, politik agama yang lebih akomodatif terhadap aspirasi Islam, dan sebagainya, adalah faktor-faktor yang ikut mendorong terjadinya pergeseran paradigma pemikiran Islam di Indonesia dalam dekade 1980-an. Dengan kata lain, pada dekade 1980-an umat Islam meredefinisikan keberadaan dan posisi politiknya

17 Lihat M. Syafii Anwar, "Negara, Masyarakat dan Artikulasi Politik Islam dalam Orde Baru," Republika, 14-15 April 1993. 
menghadapi perkembangan-perkembangan baru yang berbeda dengan masa-masa sebelumnya. ${ }^{18}$

Pergeseran pemikiran itu berdampak pada melemahnya sisa-sisa kepemimpinan politik Islam di masa lalu, termasuk sikap mereka terhadap tokoh-tokoh Islam. "Pengaruh tokoh-tokoh Islam itu," mengutip Fachry Ali, "kendati masih tetap dihormati, dengan sempurna telah terkosongkan dari ruang kesadaran politik umat, terutama di kalangan mereka yang telah terurbanisasikan". ${ }^{19}$

Ketiga, dekade 1980-an juga ditandai dengan dinamika intelektual dan kesemarakan beragama yang intens. Hal itu ditandai antara lain dengan meningkatnya penerbitan buku-buku agama, ceramahceramah dan seminar ilmiah serta berbagai aktvivitas keagamaan di kampus-kampus perguruan tinggi, padatnya jemaah masjid, semaraknya pengajian di kantor-kantor pemerintah maupun swasta, hingga meriahnya fashion show dan berbagai peragaan busana Muslim di hotel-hotel berbintang. Khususnya tentang dinamikan intelektual, terdapat fenomena pesatnya penerbitan buku-buku Islam. Sehingga tak kurang dari Bidang Perpustakaan dan Dokumentasi majalah Tempo dalam surveinya menyimpulkan bahwa kecenderungan bacaan 1980-an adalah cerminan meningkatnya kajian keagamaan. Dari sejak 7.241 buah judul buku yang dihimpunnya sejak tahun 1980, bukubuku yang bertemakan agama jumlahnya 1.949 buah. Dari jumlah terakhir itu, terdapat 809 judul $(70,5 \%)$ adalah buku bertemakan Islam, baik dari penulis-penulis Muslim Indonesia sendiri dan terutama sekali terjemahan atau saduran dari karya-karya penulis asing Muslim maupun non-Muslim. ${ }^{20}$ Yang menarik, seperti ditulis dalam laporan utama majalah Editor, penerbitan buku-buku Islam tersebut mampu merangsang diskursus intelektual (intellectual discourse) dan

\footnotetext{
${ }^{18}$ Dalam pergulatan panjang dinamika politik Islam di tanah air, para aktivis Muslim sedikitnya telah mengalami tiga kali pergeseran paradigma pemikiran: (1) Islam: ideological oriented (1920-1940-an); (2) Islam: political oriented (1945-1966); (3) Islam: programming and intellectualism oriented (1970-an-1990-an). Kendati demikian, pengelompokan orientasi pemikiran ini tidaklah mutlak, melainkan bersifat entitas. Karena itu, penyebutan tahun dalam kategorisasi di atas bukanlah bermakna sebagai pembatasan ketat, tapi sekadar sebagai bentuk simplifikasi dari kecenderungan pemikiran Islam yang dominan saat itu.

${ }^{19}$ Fachry Ali, "Akomodasi Non-Politik Islam Indonesia dalam Struktur Orde Baru," Prisma, No. 3 Tahun XX (Maret 1991), 194.

20 Nico J. Tampi, "Trend Bacaan 1980-an: Cermin Meningkatnya Telaah Keagamaan," Diskusi Buku Agama, Bagian Perpustakaan dan Dokumentasi Majalah Tempo, Jakarta, 1987.
} 
penerbitannya pun dimotori penerbit-penerbit yang dirintis oleh kalangan muda. Ternyata hasilnya, bukan saja secara kuantitatif berkembang, tapi secara kualitatif juga dapat dibanggakan. ${ }^{21}$

Dekade 1980-an juga ditandai dengan maraknya diskusi dan seminar serta dialog-dialog pemikiran baik intra umat Islam maupun antar-umat beragama, yang melibatkan pemikir-pemikir dan ilmuan baik Muslim maupun non-Muslim di pusatu-pusat pendidikan tinggi dan kota-kota universitas di Indonesia. Di kalangan intra umat Islam, dialog yang intens berlangsung antara Muhammadiyah dan NU-dua Ormas Islam terbesar di Indonesia-khususnya di lingkungan elit atau pun generasi mudanya. Dialog itu berdampak sangat luas terhadap "pergesekan pemikiran" di antara kedua belah pihak. Ditunjang dengan keterbukaan dan pesatnya memperoleh dan mengakses informasi baik dari khazanah tradisional maupun kontemporer, dialog dan diskursus berdampak pada semakin mencairnya dikotomi "tradisionalis-modernis" dalam pemikiran kaum Muslim. ${ }^{22}$

Dalam konteks ini, perlu dicatat peran dari Abdurrahman Wahid yang mengondisikan dan mendorong the emerging intellectuals di kalangan muda NU. Bahkan dengan keberaniannya yang luar biasa untuk sewaktu-waktu berbeda dengan mainstream pemikiran umat, Abdurrahman menerobos sekat-sekat ideologis dan psikologis bagi dialog dan kerjasama antara Muslim dan non-Muslim. Sementara di kalangan Muhammadiyah, M. Syafi'i Maarif adalah tokoh yang banyak mendorong kalangan muda organisasi ini untuk berpikir terbuka, kritis, dan dialogis dengan kelompok-kelompok lainnya. Kedekatan hubungan personal tokoh ini dengan elit NU di pusat maupun daerah, telah memungkinkan ia melakukan berbagai terobosan bagi terciptanya saling pengertian dan persentuhan pemikiran keislaman di antara kedua ormas Islam tersebut. ${ }^{23}$

\footnotetext{
${ }^{21}$ Lihat Editor, 14 Mei 1987. Menyusul gemuruh penerbitan buku-buku Islam di tahun 1980-an itu, juga terbit sejumlah majalah, jurnal, tabloid atau buletin Islam yang baru, sekalipun tak semua penerbitan itu mengalami sukses. Majalah, jurnal, dan tabloid Islam yang terbit dekade 1980-an antara lain adalah Risalah, Amanah, Pesantren, Ulumul Qur'an, Salman Kau, Islamika, dan lain-lain.

22 Masalah mencairnya dikotomi "tradisionalis-modernis" telah dikaji secara amat mengagumkan oleh Fachry Ali dan Bahtiar Effendy dalam buku mereka, Merambah Jalan Baru Islam: Rekonstruksi Pemikiran Islam Indonesia Masa Orde Baru (Bandung: Mizan, 1986), 167-170. Demikian juga Anwar, Pemikiran dan Aksi Islam, 125-126.

${ }^{23}$ Ibid.
} 
Fenomena-fenomena kultural dekade 1980-an, seperti yang telah dikemukan di atas, kelak sangat besar dampaknya bagi perkembangan dan masa depan Islam pada dekade 1990-an. Khusus dalam hal kebangkitan intelektualisme Islam yang ditandai dengan pesatnya penerbitan buku-buku agama dan kajian keislaman, Nurcholish memprediksikan, "akan banyak mempengaruhi kehidupan bangsa secara amat menentukan." Karena itu dapat dikatakan, fenomenafenomena tersebut, langsung atau tidak, belakangan justru telah menjadi faktor sangat signifikan yang mendorong lahir dan berdirinya Yayasan Wakaf Paramadina.

\section{Paramadina dan Wahana Intelektual Masyarakat Islam Urban}

Yayasan Wakaf Paramadina-selanjutnya disebut Paramadinaadalah lembaga keagamaan yang secara tegas menyadari keterpaduan antara keislaman dan keindonesiaan sebagai perwujudan dari nilai-nilai Islam yang universal, berkaitan dengan tradisi lokal Indonesia. Bagi pendirinya, Paramadina dirancang untuk menjadi pusat kegiatan keagamaan Islam yang kreatif, konstruktif dan positif bagi kemajuan masyarakat, tanpa sikap-sikap defensif dan reaktif. Karena itu, program pokok kegiatannya diarahkan kepada peningkatan kemampuan menjawab tantangan zaman dan menyumbang tradisi intelektual yang terus menaik dalam masyarakat. Ini berarti pertaruhan pada kualitas dan otoritas yang tinggi.

Karena itu, bukan tanpa alasan mengapa para pendiri yayasan ${ }^{24}$ ini memandang signifikan merumuskan "wawasan asasi Paramadina" sebagai platform yayasan dalam melaksanakan sejumlah aktivitasnya. Wawasan asasi yang bersumber dari ajaran-ajaran Islam-dengan senantiasa mengikuti petunjuk Kitab Suci dan Sunnah-juga dimaksudkan untuk memperkokoh landasan kegiatannya. Bagi para pendirinya, yayasan ini dibentuk guna menjadi wahana pelaksanaan rasa tanggung jawab mereka kepada bangsa dan negara sebagai

\footnotetext{
24 Paramadina didirikan berdasarkan kesepakatan sembilan belas orang anggota: Abdillah Taha, Abdul Latif, Ahmad Ganis, Ahmad Rifai, Amir Imam Puro, Aniswaty Machnan Kamaluddin, Darmin Palaon Siregar, Darnis Habid, Djohan Effendy, Fahmi Idris, Mohammad Yahya, M. Dawam Rahardjo, Musooly Noor, Mustafa Anis, Nurcholish Madjid, Sugiat Ahmad Sumadi, Tawang Alun, Usep Fathuddin, dan Utomo Danandjaya. Para pendiri ini lalu menyusun pengurus harian untuk selanjutnya disahkan lewat Notaris Yudo Paripurno, S.H. Nomor 40, tanggal 8 Juli 1986.
} 
perwujudan ibadat dan bakti mereka kepada Allah, Tuhan Yang Maha Esa.

Sebanding dengan kesejajaran manunggal antara keislaman dan keindonesiaan, wawasan asasi berdasarkan keislaman pada hakikatnya menyatu dengan wawasan asasi keindonesiaan berdasarkan nilai-nilai dalam Pancasila yang telah mantap sebagai nilai-nilai kesepakatan luhur bangsa Indonesia. Kesejajaran itu menyatakan diri dalam bentuk hubungan saling menopang antara keduanya. Yaitu bahwa ajaranajaran agama (Islam) menyediakan bahan yang kaya dan tak habishabisnya untuk pengisian nyata nilai-nilai Pancasila, dan Pancasila memberi kerangka konstitusional bagi pelaksanaan nilai-nilai keislaman di Indonesia sehingga semakin relevan dengan masalah bangsa dan negara. ${ }^{25}$

Selanjutnya secara simplistis dapat dikemukakan bahwa Wawasan Asasi Paramadina ${ }^{26}$ yang dibangun di atas visi integral keislaman dan keindonesiaan itu, lebih jauh dapat dirinci sebagai berikut:

Pertama, wawasan keimanan; beriman kepada Allah, Tuhan Yang Maha Esa, yang melahirkan nilai-nilai rabbānīyah, yaitu nilai hidup yang sepenuhnya menginsafi bahwa seluruh yang ada ini termasuk manusia, berasal dari Tuhan dan menuju kepada Tuhan (inná lilläh wa innā ilayh räji'ūn).

Kedua, wawasan titik temu; bahwa ketuhanan Yang Maha Esa adalah titik temu (kalimah sawä) antara semua agama kitab suci dan tradisi autentik, karena ajaran dasar semua utusan Tuhan ialah agar manusia menyembah hanya kepada-Nya saja.

Ketiga, wawasan kekhalifahan; Tuhan menciptakan manusia sebagai puncak ciptaan-Nya. Manusia diangkat sebagai wakil-Nya di bumi. Karena itu, manusia harus bertindak dengan penuh rasa tanggung jawab dan kesadaran akan tindakannya itu. Ini merupakan bagian dari perwujudan sikap pasrah diri (al-isläm) kepada Allah.

Keempat, wawasan Tuhan sebagai otoritas mutlak; Pengakuan yang tulus bahwa Tuhan adalah satu-satunya sumber otoritas yang serba mutlak, menghasilkan sikap bahwa semua yang terjadi di muka bumi

\footnotetext{
25 Nurcholish Madjid, "Keislaman dan Keindonesiaan: Menatap Masa Depan" prelaminay draft Wawasan Asasi Yayasan Wakaf Paramadina, [t.t], 12-13. Penegasan sikap Paramadina tentang visi integral: keislaman-keindonesiaan, dapat dipandang sebagai sikap kritis yayasan ini terhadap ketegangan konseptual selama ini tentang ideologi. Karena itu, bagi yayasan ini, seorang Muslim tidak boleh mengalami split personality: antara dirinya sebagai seorang Muslim dan sebagai warga bangsa.

${ }^{26}$ Lihat Pandangan Dasar Yayasan Wakaf Paramadina, 1986, 3-5.
} 
dan di antara manusia akan senantiasa berubah dan berkembang. Sebagai Wujud Mutlak, Tuhan adalah Kualitas Yang Tak Terbatas dan Tak Terhingga serta tidak akan berubah, dan kepada-Nya itulah manusia menuju dalam proses pendekatan terus menerus mengikuti jalan lurus yang berhimpit dengan hati nurani dan dilandasi bidāyah dan 'ināyah.

Kelima, wawasan kefitrahan manusia; manusia adalah makhluk berkecenderungan kepada kebenaran, kebaikan, dan kesucian (albanafiyah al-sambah). Wawasan kefitrahan menumbuhkan pandangan yang positif, optimis kepada sesama manusia, srta mengembangkan sikap saling percaya dan manusia semuanya mempunyai nilai yang sama, termasuk berkenan hak dan kewajiban.

Keenam, wawasan keterbukaan; Sikap pasrah yang memutlakkan Tuhan, dan gabungannya dengan pandangan yang optimis-positif kepada sesama manusia seharusnya menghasilkan tatanan sosial yang terbuka, demokratis dan adil dengan sikap melawan setiap bentuk tatanan sosial tiranik. Pengangkatan sesama manusia sebagai penguasa mutlak (täghüt) adalah sikap menyalahi prinsip Ketuhanan Yang Maha Esa (tawhid) dan kefitrahan manusia.

Ketujuh, wawasan persamaan martabat; seluruh umat manusia memiliki harkat dan martabat asasi yang sama. Tak seorang pun hendak merendahkan atau menguasai harkat dan martabat manusia lain. Karena itu, tidak dibenarkan adanya pemaksaan terhadap pribadi lain dalam bidang apapun.

Kedelapan, wawasan amaliah (praksis); Eksistensi dan esensi manusia sebagai makhluk moral ada dalam dan melalui kegiatan atau amalnya. Melalui amal perbuatannya itulah manusia menjadi "ada," dan berdasarkan amal perbuatan itu pula manusia mendapatkan penilaian benar-salah, baik-buruk, dan tinggi-rendah. Dengan kata lain, melalui amal perbuatan itu manusia menampilkan dirinya sebagai makhluk moral.

Kesembilan, wawasan kebebasan dan musyawarah; nilai manusia sebagai makhluk moral (yaitu makhluk yang akan dimintai pertanggung jawaban atas segala perbuatannya, baik dan buruk), mengasumsikan kebebasan diri pribadinya dalam memilih tindakantindakan yang dianggapnya baik. Tetapi karena manusia mustahil mengetahui Kebenaran Mutlak (yang hanya menjadi milik Tuhan), maka pengetahuan manusia itu, betapapun tingginya, adalah tetap terbatas. Karena itu, setiap orang dituntut untuk cukup rendah hati 
guna bisa mengakui adanya kemungkinan orang lain di antara sesamanya yang mempunyai pengetahuan lebih tinggi.

Kesepuluh, wawasan kerjasama; kerjasama antar-manusia diperlukan agar potensinya untuk benar dan baik guna mengatasi kelemahannya sebagai individu yang terbatas. Maka kerjasama atas dasar kemauan baik dan rasa taqwa kepada Allah akan meningkatkan kualitas hidup hakiki manusia.

Kesebelas, wawasan hidup berorganisasi; kerjasama berakar dalam sikap saling menghormati dan saling memuliakan. Sebagaimana prinsip musyawarah yang melahirkan adanya hak menyatakan pikiran sendiri, dan kewajiban mendapat pikiran orang lain, kerjasama antarmanusia menuntut adanya hubungan "menerima dan memberi" (take and give), yang dalam bentuk konkretnya melahirkan wawasan hidup berorganisasi. Hubungan yang saling mengisi dan saling menopang masing-masing dengan unsur-unsur kekuatan dan kelemahannya akan memperkokoh wawasan kesamaan harkat dan martabat manusia, dan akan lebih menjamin tercapainya tujuan bersama.

Kedua belas, wawasan kemajemukan; jalan umat manusia menuju dan merealisasikan kebenaran amat dipengaruhi oleh ruang dan waktu. Setiap kelompok manusia dalam sejarahnya telah mendapat petunjuk Allah melalui para rasul-Nya. Mereka berhak atas kesempatan melaksanakan ajaran mereka itu, selama hal itu bukanlah pengingkaran kepada prinsip keharusan pasrah penuh ketulusan dan kedamaian kepada Tuhan. Karena itu, seriap orang berkewajiban untuk saling menghormati dan melindungi serta menilai sesamanya secara adil, dalam setiap wawasan yang pluralisme.

Kutipan amat panjang tersebut sengaja dikemukan di sini, sebab dari wawasan itulah visi, misi dan seluruh aktivitas Paramadina kemudian dibangun. Dengan wawasan itu pula-mengutip Nurcholish_- Paramadina menatap masa depan bangsa dan tanah air dengan penuh harapan kepada Allah, Tuhan Yang Maha Esa. Masa depan yang cerah mesti disongsong dengan kesadaran akan pluralisme sosial dalam suatu wadah tatanan politik yang adil, terbuka dan demokratis."

Agaknya, para pendiri Paramadina sadar, saat menjatuhkan pilihannya untuk menyapa dan sekaligus mengajak masyarakat Islam urban, khususnya Jakarta, guna menikmati layanan sosial Paramadina berupa Program Studi Islam. Sebab para pengelola Paramadina memandang jika masyarakat Islam urban-untuk menghindarkan 
istilah "kelas menengah kota" 27 -adalah segmen masyarakat Islam yang langsung atau tidak "paling siap" menangkap gejala kebangkitan intelektualisme Islam di tanah air. Mereka umumnya tidak memiliki pemahaman keagamaan Islam yang memadai, walaupun secara formal mereka tergolong kaum terpelajar baik secara intelektual, finansial atau pun kultural. Pendidikan mereka umumnya dari Barat, atau setidaknya sarjana lulusan perguruan tinggi "umum." Tapi tak sedikit dari mereka mengalami stigma di masa lalu, yaitu pengalaman kurang simpatik terhadap Islam.

Kesadaran beragama di kalangan masyarakat urban mulai bangkit bersamaan dengan mewabahnya satu penyakit kronis masyarakat modern: krisis spiritual. Dengan demikian mereka sebenarnya telah kehilangan apa yang dalam istilah filsafat disebut sebagai meaning and purpose of life.

Dalam situasi seperti inilah, manusia modern-yang ditemukan bentuknya terutama dalam kehidupan masyarakat perkotaan-kian menyadari jika terdapat sesuatu yang telah 'hilang' dalam diri mereka. Mereka membutuhkan sebuah wacana guna menemukan ketenangan jiwa. Gelimangan harta dan jabatan agaknya tak mampu menenangkan kegelisahannya. Bagi mereka, yang dibutuhkan sesungguhnya adalah sesuatu yang tataran nilainya jauh di atas materi. Pada saat itulah manusia membutuhkan keheningan jiwa dan kegairahan spiritual.

Menyadari fenomena itu, Paramadina lantas menawarkan sejumlah paket studi keagamaan Islam dengan metode belajar yang relatif membebaskan, kritis dan demokratis. Suasana "dialogis" pun tercipta dengan sendirinya. Karena itu, Paramadina di sini tidak saja menawarkan paket studi Islam yang tersistematis dan disampaikan oleh narasumber yang populer, tetapi sekaligus menawarkan "terapi" spiritual dan intelektual guna menjawab kekosongan makna hidup bagi mereka yang mengalami kegalauan akibat gemuruh modernisasi.

\footnotetext{
27 Disadari sepenuhnya jika istilah "kelas menengah kota" dalam perspektif keagamaan cenderung menyesatkan, karena istilah ini biasanya dipahami secara kuantitatif dengan menggunakan tolok ukur variabel ekonomi dan kesarjanaan, sementara kualitas etis dan ketakwaan seseorang tidak selalu secara signifikan berkolerasi positif dengan kekayaan dan kepintaran. Karena itu, kita tak perlu heran misalnya jika seseorang yang secara ekonomi bisa dibilang "konsumsi kelas lembek" tapi memiliki moralitas cukup tinggi daripada yang pertama. Dengan demikian, penggunaan istilah "masyarakat urban" dalam tulisan ini diharapkan lebih "netral" dan dipahami secara lentur, dengan tetap mempertimbangkan suara nurani yang tidak silau terhadap gemerlapnya etalase kemewahan materi yang menjadi trend sebagian kecil masyarakat Indonesia, khususnya Jakarta.
} 
Dengan kata lain, Paramadina didirikan sebagai pusat pengkajian Islam yang bersifat akademis dan berorientasi pada pengisian nilainilai keislaman bagi para elit menengah Muslim di perkotaan.

Secara jangka panjang, Paramadina bermaksud mencetak pribadi Muslim yang berwawasan keislaman dan keindonesiaan, serta diharapkan sebagai penentu kecenderungan bangsa ke depan. Untuk maksud tersebut, Paramadina merancang sejumlah aktivitasnya berupa Program Studi Islam, baik dari segi kelembagaan maupun kegiatan intelektual keagamaan.

Maka program pokok kegiatan berkisar pada peningkatan dan penyebaran paham keagamaan Islam yang luas, mendalam, dan bersemangat keterbukaan dengan titik berat pada: pertama, pemahaman sumber-sumber ajaran Islam, khususnya masa lahir dan proses pembentukannya, dalam kaitannya dengan lingkungan sosial, politik, ekonomi, budaya dan lain-lain. Kedua, penyadaran tentang sejarah pemikiran Islam, suatu relasi dialektis antara ajaran dan peradaban yang terjadi dan berlangsung dalam panggung sejarah umat Islam. Ketiga, apresiasi terhadap khazanah budaya dan peradaban Islam dan bangsa-bangsa Muslim. Keempat, penanaman semangat nonsektarian dan pengembangan serta pemeliharaan Ukhumwah Islamiyah yang berkonotasi dinamis dan kreatif. Kelima, pendalaman dan perluasan studi perbandingan mazhab-mazhab dan aliran-aliran dalam Islam, antara lain guna menghindari kecenderungan sikap anarkis dan eksklusivistik. Keenam, pengembangan sikap-sikap penuh toleransi dan apresiatif terhadap kelompok-kelompok agama lain untuk menciptakan masyarakat yang damai (saläm) sebagaimana hal itu diajarkan oleh Islam. ${ }^{28}$

Dalam Mukaddimah pendirian Paramadina disebutkan, untuk mengembangkan serta mencapai maksud dan tujuan Paramadina tersebut, maka langkah yang dilakukan adalah:

1. Menyelenggarakan pendidikan keislaman integral untuk kalangan tertentu masyarakat dengan maksud semakin menopang terjadinya penerimaan ajaran Islam secara merata dan menyebarkannya sebagai ramuan pokok pengembangan nilai keindonesiaan sejati mengikuti Pancasila sebagai dasar bersama.

2. Menyelenggarakan pendidikan keislaman integral untuk generasi muda guna menyebarkan dan mengukuhkan suatu pemahaman

28 Lihat "Yayasan Paramadina" dalam Budhy Munawar-Rachman (ed.), Kontekstualisasi Doktrin Islam dalam Sejarah (Jakarta: Paramadina, 1994), 731. 
ajaran Islam secara berimbang, menyeluruh, padu, padat dan utuh sebagai pembawa kebaikan untuk semua (rahmah li al-álamin).

3. Mendirikan perguruan tinggi dan pusat kajian keilmuan yang bermutu dan berwibawa dalam semangat keislaman yang integral, sebagai penyiapan dan penyongsongan masa depan. Untuk itu Paramadina mengambil ruang lingkup kegiatan dan aktivitasnya sebagai berikut:

A. Menggalakkan kajian konsep keislaman yang hakiki dan mengintegrasikannya dengan pengembangan konsep dinamika kehidupan masyarakat yang sedang membangun.

B. Membina jaringan kerja kooperatif antar-pusat kajian konsep dinamika kehidupan yang bernafaskan Islam tingkat nasional.

C. Mengupayakan sintesa kajian konsep dinamika kehidupan untuk disepakati, dipakai sebagai landasan keabsahan kegiatan operasional pembangunan masyarakat untuk kurun waktu yang berkenaan dengan kebutuhannya.

D. Mengkaji metode-metode balajar mengajar dan dakwah Islam sesuai kebutuhan.

E. Membina dan menumbuhkan lembaga-lembaga pendidikan dan dakwah Islam sebagai wahana penerapan pengembangan cara berpikir yang efektif.

F. Menjalin hubungan interaktif dengan berbagai pusat keunggulan kajian Islam dan pusat keunggulan kajian kehidupan masyarakat tingkat internasional.

G. Melaksanakan paket-paket kegiatan yang sesuai dengan misi Paramadina untuk membantu pemecahan permasalahan jangka panjang di sektor pendidikan, pembinaan dunia usaha, peningkatan produktivitas kerja dan penerapan ilmu penegtahuan dan teknologi.

H. Meningkatkan kemampuan tenaga dan sarana untuk mendukung operasi Paramadina.

I. Melaksanakan sistem pengelolaan kelembagaan yang dinamis sesuai perkembangan tuntutan lingkungan.

J. Mengupayakan dan mengelola pengembangan sumber dana untuk membiayai pengembangan wahana dan konsisten dalam aspek yang terkait dengan misi Paramadina. ${ }^{29}$

Berikut akan dikemukakan sejumlah kegiatan dan amal usaha yang telah dilaksanakan oleh Paramadina.

${ }^{29}$ Lihat, Pandangan Dasar Yayasan Wakaf Paramadina, 8-10. 


\section{Klub Kajian Agama (KKA)}

Mungkin tak berlebihan jika dikatakan, dari seluruh aktivitas dini Paramadina, KKA boleh dipandang sebagai trademark yayasan ini. Awalnya, KKA dilaksanakan sebulan sekali di sebuah hotel berbintang yang diikuti tak kurang dari 200-300 peserta dan umumnya adalah anggota Paramadina. Belakangan, aktivitas KKA dilangsungkan di kawasan Pondok Indah, kantor di mana yayasan ini berada.

Pada setiap acara KKA, diupayakan menampilkan para pembicara yang populer dari kalangan cendekiawan Indonesia. Tema-tema kajiannya pun aktual serta penyediaan sarana pengajian yang menarik berupa tempat dan suasana yang bersih dan nyaman, penyediaan snack, musik ringan, dan sebagainya. Kecuali anggota Paramadina, setiap peserta umum wajib membayar setiap paket kajian sebesar Rp 25.000,- dan mahasiswa Rp 10.000,-.

Dari forum ini lazimnya menampilkan dua makalah: narasumber tamu dan dari Paramadina sendiri. Untuk aktivitas awalnya, Nurcholish Madjid selalu mewakili Paramadina. Dari makalahmakalah itu, kelak diterbitkan dalam bentuk buku sebagai salah satu aktivitas seri penerbitan Paramadina.

Kajian yang bersifat bebas dan non-sektarian ini, pada urutannya mengundang minat non-Muslim untuk mengikutinya. Pimpinan dan anggota Paramadina berkeyakinan bahwa semangat untuk berkreasi hanya bisa lahir dari suasana kebebasan dan keterbukaan. Karena itu, tak berlebihan jika dikatakan, segenap anggota Paramadina adalah penganut "sekte" kebenaran, mengingat forum-forum kajian Paramadina laksana "warung kopi" ilmiah dan religius, di mana pesertanya berasal dari latar belakang sosial, kultural, dan agama yang beragam.

Berdasarkan data yang ada pada mailing list Paramadina, ${ }^{30}$ jumlah anggota KKA hingga saat ini sekitar 2000 orang, di samping yang aktif dikirimkan surat pada setiap pengajian atau kajian sekitar 1000 orang. Mengenai sumberdana yayasan, di samping adanya sponsor tetap seperti di antaranya dari Aburizal Bakrie, Paramadina juga memiliki sumberdana rutin dari anggota tetap dengan cara mengumpulkan dana abadi perorang $\mathrm{Rp} 1.000 .000$,- pertahun. Sementara untuk tetap menjaga komunikasi dan dialog para alumni/ jemaahnya, yayasan ini menyiapkan wadah yang disebutnya "Serambi Paramadina."

${ }^{30}$ Lihat Mailing List Paramadina, 1998. 


\section{Kursus Studi Islam}

Salah satu kegiatan Paramadina yang mendapat minat cukup tinggi dari peserta adalah layanan sosial berupa kursus atau perkuliahan serta seminar dengan tema-tema utama seputar ilmu keislaman, masalahmasalah sosial keagamaan dan persoalan-persoalan etika berbangsa dan bernegara. Program-program itu dirancang dan disusun sedemikian rupa seperti halnya materi kuliah di perguruan tinggi, masing-masing penyampaian mata kuliah memerlukan waktu tatap muka antara 12-16 kali dua jam, diselenggarakan sekali dalam seminggu. Setiap mata kuliah rata-rata diikuti oleh 40 orang peserta, sementara jumlah mata kuliah berkembang secara fleksibel dengan rujukan khazanah intelektual Islam klasik yang dikontekstualisasikan pada kehidupan modern serta mempertimbangkan permintaan para peserta.

Animo peserta kian menguat, terutama karena paket ini didukung oleh dosen populer dan dipandang memiliki otoritas di bidangnya. Sebut saja misalnya, Nurcholish Madjid, M. Quraish Shihab, Jalaluddin Rakhmat, Komaruddin Hidayat, Azyumardi Azra, K.H. Ali Yafie, Kautsar Azhari Noer, Abdul Hadi WM, Marwah Daud Ibrahim, M. Dien Syamsuddin, Munawir Syadzali, Harun Nasution, M. Dawam Rahardjo, Djohan Effendi, Zainun Kamal, Mulyadhi Kartanegara, M. Amin Abdullah dan lain sebagainya.

Mengingat sebagian besar peserta masih aktif bekerja, maka perkuliahan dilaksanakan sore hari, kecuali hari sabtu yang berlangsung dari pagi sampai sore. Selain perkuliahan yang diselenggarakan di kantor sekretariat Pondok Indah, Paramadina juga memenuhi beberapa permintaan dari kantor atau perusahaan yang ingin menyelenggarakan in-house-class bagi para karyawannya. Ini semua merupakan data ataupun indikator kongkret bahwa peserta dan peminat Studi Islam Paramadina datang dari kelas menengah ke atas. Tetapi perlu diingat bahwa kata "kelas menengah ke atas" sekali lagi, tidak serta merta menggambarkan bahwa tingkat pemahaman mereka tentang Islam juga sudah tinggi. Dalam berbagai hal justru sebaliknya. Menurut Direktur Pelaksana Paramadina Komaruddin Hidayat, peserta yang ada—baik yang aktif maupun non-aktif—kurang lebih berjumlah 1.500 orang. Ini belum terhitung peminat Studi Islam 
Paramadina yang di selenggarakan di perkantoran atau perusahaan yang mengambil paket in-house-class. ${ }^{31}$

Budhy Munawar-Rachman-Koordinator Program Studi Islam Paramadina—di satu kesempatan menjelaskan bahwa hasil dari kajian dan perkuliahan itu direkam dalam kaset dan diterbitkan menjadi Kamus Leksikon Paramadina. ${ }^{32}$

Satu hal yang menarik dalam atmosfir perkuliahan di Paramadina adalah suburnya pemahaman keagamaan yang beragam dari peserta maupun narasumber. Hal ini disebabkan antara lain karena agama (Islam) yang dikaji, kendatipun diyakini sebagai agama wahyu yang bersifat transhistoris karena datang dari Tuhan-sebagaimana pula keyakinan serupa terjadi pada pemeluk agama lain terhadap agamanya-namun kenyataannya yang sampai kepada kita adalah himpunan informasi, doktrin dan ajaran yang sudah terbungkus dalam paket-paket produk sejarah. Jadi tak lebih sekadar human construction. Dengan kata lain, Program Studi Islam Paramadina sangat menghargai perbedaan pendapat, dan memberi kebebasan seluas-luasnya kepada peserta untuk mengemukakan argumentasinya sekaitan dengan pemahaman keagamaan tertentu yang diyakininya selama ini. Karena itu, dengan sendirinya tercipta satu dialog intensif dan kreatif baik antarsesama peserta maupun peserta-narasumber. Dengan kata lain, iklim perkuliahan Paramadina, sangat demokratis, terbuka dan dialogis. Karena iklim intelektual seperti itulah, sehingga tak berlebihan jika di Paramadina, upaya untuk melihat secara kritis terhadap pertumbuhan tradisi pemikiran Islam sangat dimungkinkan, karena pada urutannya kita bisa memilih manakah tradisi yang masih relevan untuk dipertahankan dan mana yang perlu direvisi.

Untuk menambah wawasan lebih luas lagi, sewaktu-waktu Paramadina juga mengundang pembicara tamu dari luar negeri baik yang Muslim mapun non-Muslim. Sejauh ini, para peserta merasa menikmati iklim diskusi yang terbuka serta pendekatan Islam yang inklusif. Tentu saja tidak semua peserta setuju dengan materi kuliah yang mereka terima. Bahkan tidak semua dosen memiliki pendapat yang sama. Namun, mengutip Komaruddin Hidayat, "iklim yang

31 Lihat Komaruddin Hidayat, "Studi Islam di Paramadina" dalam M. Dawam Rahardjo (ed.) Tragedi Raja Midas: Moralitas Agama dan Krisis Modernisme (Jakarta: Paramdina, 1998), 204-205.

32 Ngobrol santai penulis dengan Budhy Munawar-Rachman, sesaat setelah diskusi di Paramadina, "Kultur Politik Orde Baru: Ketegangan antara Kultur Pesisir dan Kultur Pedalaman,” 7 September 1996. 
seperti inilah yang dipelihara Paramadina sebagai bagian dari upaya menumbuhkan pemahaman keagamaan yang inklusif." ${ }^{33}$ Tidak hanya paham inklusivisme beragama, bahkan tren global cenderung mendesakkan paham pluralisme beragama. Agaknya, kecenderungan ini secara sadar dicoba diantisipasi Paramadina, melalui sajian paketpaket kuliah agar para peserta lebih siap, baik secara intelektual maupun psikologis, memasuki pergaulan dan wacana global.

3. LAZIS

Lembaga Amil Zakat Infak dan Sedekah (LAZIS) Paramadina adalah lembaga otonom dalam lingkungan Yayasan Wakaf Paramadina yang mengumpulkan zakat, infak dan sedekah kaum Muslim, yang akan digunakan untuk memerangi kemiskinankhususnya kemiskinan intelektual-dengan membiayai programprogram penerbitan, beasiswa, penelitian, dan lain-lain program yang sejalan dengan tujuan Yayasan Wakaf Paramadina. ${ }^{34}$ Hingga kini, LAZIS Paramadina telah membiayai program penerbitan buku atas karya-karya kesarjanaan sejumlah cendekiawan Muslim di tanah air. ${ }^{35}$

Karena itu, kehadiran lembaga ini, kendati pun usianya boleh dibilang masih relatif muda, tetapi dari penerbitan yang dibiayainya telah memperlihatkan "kelas" tersendiri di tengah-tengah maraknya penerbitan di tanah air.

\footnotetext{
${ }^{33}$ Hidayat, "Studi Islam di Paramadina," 214.

${ }^{34}$ Lihat "LAZIS Paramadina" dalam Munawar-Rachman (ed.), Kontekstualisasi, 731.

${ }^{35}$ Buku-buku yang telah diterbitkan Paramadina atas biaya LAZIS antara lain: karyakarya Nurcholish Madjid, Islam Doktrin dan Peradaban: sebuab Telaah Kritis tentang Masalah Keimanan, Kemanusiaan, dan Kemodernan (1992); Pintu-pintu Menuju Tuhan (1994); Islam Agama Kemanusiaan: Mebangun Tradisi dan Visi Baru Islam Indonesia (1995); Islam Agama Peradaban: Membangun Makna dan Relevansi Doktrin Islam dalam Sejarah (1995); Kaki Langit Peradaban Islam (1997); Tradisi Islam: Peran dan Fungsinya dalam Pembangunan di Indonesia (1997); Nasir Tamara dan Elza Peldi Taher (eds.), Agama dan Dialog Antar Peradaban (1996); M. Wahyuni Nafis (ed.), Kontekstualisasi Ajaran Islam: 70 Tabun Prof. Dr. H. Munawir Syadzali, MA (1995); Agama Masa Depan: Perspektif Filsafat Perennial (1995); Rekonstruksi dan Renungan Religius Islam (1996); Budhy Munawar-Rachman (ed.), Kontekstualisasi Doktrin Islam dalam Sejarah (1994); Ensiklopedi al-Qur'an karya M. Dawam Rahardjo (1996); Azyumardi Azra, Pergolakan Politik Islam: dari Fundamentalisme, Modernisme, hingga Post-Modernisme (1996); M. Syafi'i Anwar, Pemikiran dan Aksi Islam Indonesia: sebuah Kajian Politik tentang Cendekiawan Muslim Orde Baru (1995); Hanna Djumhana Bastaman, Meraib Hidup Bermakna (1996); Komaruddin Hidayat, Memahami Bahasa Agama: sebuab Kajian Hermeneutik (1996); Tragedi Raja Midas: Moralitas Agama dan Krisis Modernisme (1998) serta kerjasama Paramadina-Gramedia, Komaruddin Hidayat \& Ahmad Gaus (eds.), Passing Over: Melintasi Batas Agama (1998).
} 


\section{High Boarding School Madania}

High Boarding School (SMU) Madania adalah salah satu dari sekian amal usaha Paramadina yang bergerak di bidang penyediaan sekolah unggulan. Dengan kata lain, sekolah ini dimaksudkan sebagai "lembaga pendidikan alternatif" terutama sesaat setalah menyaksikan kian merosotnya kualitas pendidikan SMU di Indonesia.

Dalam kurikulumnya-di samping merujuk kepada Kurikulum Pendidikan dan Kebudayaan-juga memberi bobot tambahan yang relevan dengan kehidupan modern serta mencerahkan intelektualitas dan spiritualitas siswanya. Sebab, seperti diyakini pengelola lembaga ini, dunia modern telah cenderung memisahkan orang-orang cerdas dan kreatif dari akhlak, atau menjauhkan orang-orang berakhlak dari kecerdasan dan kreativitas. Untuk yang terakhir ini, para siswa diberi mata pelajaran keislaman yang relatif komprehensif, dengan titik penekanan pada pemikiran filosofis. Dengan kata lain, filsafat Islam di sini menjadi paradigma dalam mencandra seluruh bangunan keilmuan dalam tradisi Islam.

Untuk memudahkan siswa mengakses khazanah intelektual Islam klasik dan informasi-informasi pengetahuan modern, maka lembaga ini juga menyediakan program pendidikan bahasa asing secara intensif, khususnya bahasa Arab, Inggris dan Jerman. Di samping itu, diberi pula tambahan pelajaran berupa teknik informatika dan komputer. Salah satu ciri menonjol lembaga ini, dalam kurikulumnya dicantumkan pula materi teknik penulisan karya ilmiah. Hal ini dimaksudkan sebagai intellectual exercise para siswa dalam menuangkan gagasannya secara tertulis.

Menurut direktur High Boarding School Madania Ahmad Fuadi, "menyimak program-program pendidikan yang ditawarkan, dengan tenaga pengajar yang qualified, agaknya tak berlebihan jika dikatakan bahwa lembaga ini memiliki prospek yang cerah." Lebih lanjut dikatakan, "para alumninya yang kelak ingin melanjutkan studidengan berbekal prestasi akademik yang tinggi-akan mampu bersaing dengan rekannya untuk memperebutkan bangku di perguruan tinggi baik di dalam maupun di luar negeri. Sementara yang ingin terjun di dunia kerja-bekal keterampilan bahasa asing, ilmu pengetahuan keislaman yang memadai, dan teknik informatika komputer-jelas akan membuka peluang yang cukup lebar. Sehingga 
kesenjangan antara dunia pendidikan dan dunia kerja secara perlahan dapat dirampingkan". ${ }^{36}$

Lebih dari itu, lembaga pendidikan ini agaknya, hendak berpartisipasi lebih jauh dalam melahirkan generasi muda yang pada diri siswa-siswanya terintegrasi intelegensia, kreativitas, dan berakhlak mulia.

5. Universitas Paramadina Mulya

Sebagaimana tercantum dalam Wawasan Asasi Paramadina, bahwa untuk mencapai tujuan yayasan, salah satu langkah yang dapat ditempuh adalah membina hubungan interaktif dengan berbagai pusat keunggulan kajian Islam ataupun pusat keunggulan kajian kehidupan masyarakat baik di tingkat nasional maupun internasional. Dari perspektif inilah agaknya kita bisa memandang keberadaan Universitas Paramadina Mulya.

Universitas Paramadina Mulya didirikan oleh Yayasan Paramadina Mulya dengan Akta Notaris Harun Kamil, SH No. 188, pada tanggal 27 Februari 1995. Yayasan Paramadina Mulya adalah yayasan dengan para pendiri berasal dari dua yayasan, yaitu Yayasan Wakaf Paramadina Mulya dan Yayasan Pondok Mulya. ${ }^{37}$

Untuk melaksanakan aktivitasnya, yayasan ini menyusun Organisasi Kerja sebagai berikut:

1. Pendiri Yayasan Paramadina Mulya

Untuk memayungi seluruh kegiatan Paramadina Mulya maka disusunlah pendiri yayasan tersebut: Sudwikatmono (Ketua), Nurcholish Madjid (Wakil Ketua), Soebagdja Prawata (Sekretaris), Soegeng Sarjadi (Wakil Sekretaris) Anggota: Aburizal Bakrie, Achmad Tirtosudiro, Adjid Hutomo, Ahmad Ganis, Budiman Kusika, Fahmi Idris, Ibrahim Risyad, Ismail Sofyan, Soekrisman, dan Utomo Danandjaya.

Sementara itu untuk mengelola Uiniversitas Paramadina Mulya dibentuklah Badan Pelaksana yang terdiri dari: Prof. Dr. Nurcholish Madjid (Rektor); Dr. Ir. Marsudi W. Kisworo, MSc. (Direktur Pascasarjana); Sudirman Said, MBA. (Sekretaris Pascasarjana); Dr. Alwi Shihab (Ketua Program Studi Ilmu Agama Islam); Dr. Mulyadhi Kartanegara (Sekretaris Program Studi Ilmu Agama Islam); Dr.Ir. Marsudi W. Kisworo, MSc. (Ketua Program Studi Magister Manajemen); Sudirman Said, MBA. (Sekretaris Program Studi

\footnotetext{
${ }^{36}$ Lihat, majalah Ummat, 27 April 1996.

${ }^{37}$ Lihat Rencana Induk Pengembangan Universitas [tidak diterbitkan, 1998], 7.
} 
Magsiter Manajemen); Kartiko Adi Pramono, Dipl. Masch.Ing.HTL. (Direktur Politeknik)

Organisasi kerja ini diharapkan dapat menjadi efektif, terutama sesaat setelah proses belajar mengajar berlangsung. Bagi para pendiri dan pengelolanya, Universitas Paramadina Mulya adalah refleksi dari kesungguhan tentang sebuah universitas, guna merespons tantangan perkembangan zaman di masa depan. Universitas ini dirancang untuk mencoba ikut menawarkan alternatif dalam usaha menciptakan keunggulan ilmiah dan kedalaman spiritual. Karena itu, secara sadar Universitas Paramadina Mulya berupaya memposisikan dirinya sebagai lembaga pendidikan tinggi yang bertujuan menghasilkan keluaran yang memiliki kedalaman iman, kepekaan nurani, ketajaman nalar, kecakapan berkarya, keluasan wawasan dan kemandirian jiwa. ${ }^{38}$

Untuk maksud dan tujuan tersebut, Universitas Paramadina Mulya menyediakan jenis pendidikan yang umum dan bebas (liberal education), yang menyiapkan peserta studi untuk secara luas mampu menghadapi masa depan yang terus menerus berkembang menuju dunia kehidupan yang berbeda dari yang ada saat ini.

Atas dasar pertimbangan sebagai penyelenggara program studi yang umum dan bebas itu, Universitas Paramadina Mulya tidak membatasi penerimaan mahasiswa sebagai peserta studi hanya kepada mereka yang memiliki latar belakang pendidikan dan disiplin ilmu formal tertentu. Tapi semua latar belakang pendidikan dan disiplin ilmu yang memiliki ketangguhan semestinya akan dipandang sebagai kesiapan akademik dan intelektual untuk ikut serta secara aktif dalam semua program studi. Karena itu, setiap bidang dan disiplin ilmu formal seorang calon peserta studi adalah transferable, yaitu diakui dan dihargai sebagai kesiapan dan kemampuan seorang peserta studi untuk melaksanakan tugas-tugas akademik dan intelektualnya dalam lingkungan universitas. Dengan kata lain, Universitas Paramadina Mulya lebih menitikberatkan penerimaan masuk mahasiswa atas dasar potensi akademik pribadi yang tinggi, tidak pada kekhususan suatu bidang studi yang dipunyai sebelumnya. ${ }^{39}$

Salah satu keunikan di Universitas Paramadina Mulya, hubungan antara para anggota staf pengajar dan para mahasiwa selaku peserta studi tak lebih dari kawan sejawat atau kolega dalam usaha bersama

\footnotetext{
${ }^{38}$ Lihat, Ibid., iv.

39 Nurcholish Madjid, Pidato Pendirian dan Pembukaan Universitas Paramadina Mulya (tidak diterbitkan), 27 Februari 1998, 6.
} 
mengembangkan ilmu dan tradisi intelektual yang tangguh. Staf pengajar memberi arahan kepada para peserta studi untuk sekitar separuh dari keseluruhan tugas akademiknya. Sementara separuhnya lagi adalah kewajiban peserta untuk memenuhinya, dengan mengembangkan inisiatif pribadi untuk melalukan riset, penjelajahan ilmiah dan pemikiran sendiri secara aktif dan kreatif. Untuk memenuhi iklim itu, pihak universitas telah menyediakan fasilitas pendukung yang memadai seperti perpustakaan, laboratoriumlaboratorium, dan bengkel-bengkel kerja (workshop).

Di samping itu, digagas dengan semangat inovasi dan terobosan melalui riset dan penelitian, universitas ini akan dilengkapi pula dengan fasilitas akademik yang diatur secara profesional. Sementara, agenda kegiatan akademik Universitas Paramadina Mulya senantiasa mengacu pada penanaman semangat menerobos "perbatasan terakhir ilmu pengetahuan" sembari mencoba mencermati kecenderungan terakhir dunia riset dan mendorong jiwa kewirausahaan (enterpreneurship) dan kepoloporan.

Semua wawasan dasar itu akan merupakan ciri khusus Universitas Paramadina Mulya. Para anggota fakultas akan "dihasut" untuk mengembangkan minat ilmiah yang cerdas dan jiwa inovatif yang berani dalam ilmu pengetauan. Wawasan dasar itu selanjutnya akan mewarnai semua bagian universitas yang meliputi tiga divisi pokok, yaitu: pertama, divisi falsafah dan ilmu peradaban (al-hikmah wa ulüm al-umrän, setara dengan humanities and social sciences); kedua, divisi ekonomi kewirausahaan (enterpreneurial ecomomics); dan ketiga, divisi ilmu rekayasa dan teknologi (science of engineering and technology). ${ }^{40}$

Mencermati wawasan dasar Universitas Paramadina Mulyadi atas, tampaklah bahwa dalam batas-batas jangkauannya, universitas ini berupaya menjawab tantangan perkembangan bangsa pada masa depan yang terus berubah serta memberi sumbangan kepada usaha memperbaiki model pendidikan yang berlaku, sambil melihat kemungkinan melahirkan model alternatif. Hal ini terlihat jelas terutama sesaat universitas ini menyiapkan dirinya sebagai pusat penelitian yang menumbuhkan "budaya riset" dan menggalakkan aktivitas-aktivitas riset profesional yang relevan dengan tantangan pembangunan: penampilan citra kampus sebagai pusat kebudayaan yang membangkitkan sikap kejiwaan yang menopang daya cipta, mengasah kepekaan etika-religius, menyuburkan semangat kemanusia-

${ }^{40}$ Ibid. 
an, saling pengertian dan toleransi. Bagi para pendirinya, Universitas Paramadina Mulyajuga diharapkan dapat menumbuhkan tradisi masyarakat ilmiah, yang di dalamnya tidak hanya berlangsung proses belajar-mengajar secara formal, tetapi keseluruhan lingkungan universitas merupakan sarana pengembangan potensi kreatif dan kepribadian teguh mahasiswa, dengan sikap menjunjung tinggi kebebasan mimbar akademik.

Dalam kaitannya dengan penyelenggaraan program pendidikanguna menghindari keadaan tumpang tindih yang tidak perlu terjadi antara berbagai jurusan studi yang telah banyak dikembangkan di Indonesia, disertai pengamatan cermat terhadap kecenderungan dan kebutuhan masa depan-maka Universitas Paramadina Mulya akan menitikberatkan program dan agendanya pada pengembangan disiplin ilmu-ilmu baru yang menjadi pengarah kecenderungan masa depan, terutama di bidang ilmu rekayasa, ekonomi kewirausahaan, serta wawasan nilai-nilai hidup dalam falsafah dan kajian keagamaan. ${ }^{41}$

Pilihan Universitas Paramadina Mulya terhadap ilmu baru seperti disebutkan di atas, bukannya tanpa alasan. Sebab, bagi Universitas ini, ketiga ilmu pokok tersebut yaitu: kesadaran etika-religius dan falsafah, kemampuan wirausaha, dan penguasaan iptek dan ilmu rekayasa, justru menjadi kunci yang menjanjikan masa depan. Iptek dan ilmu rekayasa menjadi ujung tombak pengembangan ilmu, didukung ilmu ekonomi bersemangat wirausaha yang ditopang oleh panduan etis yang lahir dari falsafah peradaban kemanusiaan, sungguh merupakan anyaman indah dalam membangun peradaban Indonesia Baru.

Harapan tersebut coba diwujudkan dengan cara membuka jenjang Program Pascasarjana, Sarjana dan Diploma. Program Pascasarjana secara spesifik diorientasikan pada bidang pengkajian ilmu-ilmu strategis yang berpengaruh utama bagi kecenderungan masa depan. Penyelenggaraan Program Pascasarjana ini mengintegrasikan dimensi hulu (etika dan ilmu dasar) dengan dimensi hilir (praktis), dan

41 Rencana Induk Pengembangan, 6. Untuk tahap pertama, Universitas Paramadina Mulya telah membuka Program Studi Falsafah dan Peradaban, tahun akademik 1998/1999. Program studi ini meliputi: studi agama, falsafah, dan peradaban, untuk jenjang S1, sementara untuk jenjang Pascasarjana, meliputi: pemikiran Islam (Islamic thought), falsafah Islam, perbandingan agama, sosiologi agama, peradaban dunia dan falsafah modern. Untuk yang terakhir ini, bahkan telah mendapat pengakuan dari Departemen Agama berdasarkan Surat Keputusan Menteri Agama No. 70 Tahun 1998, tentang Pembentukan Program Magister Ilmu Agama Islam Yayasan Paramadina Mulya. 
ditopang oleh kegiatan riset yang menjadi sendi kekuatan masyarakat industri dan kegiatan ekonomi. Untuk program Pascasarjana, setidaknya ada tiga bidang yang akan dikembangkan: (1) Bidang Ilmu Rekayasa; (2) Bidang Politik Bisnis dan Pembangunan; dan (3) Bidang Falsafah dan Peradaban. Bidang kajian terakhir sementara berjalan untuk tahun akademik 1998/1999.

Selanjutnya, Program Sarjana (S-1) memiliki orientasi kembar: sebagai pendukung bagi program studi dan keahlian yang dikembangkan dalam program Pascasarjana dan pendidikan profesionalisme sesuai dengan bidang-bidang studi. Program Sarjana ini meliputi: (1) Fakultas Matematika dan Ilmu Pengetahuan Alam; (2) Fakultas Teknologi Industri; (3) Fakultas Rancang Bangun; (4) Fakultas Ekonomi dan Bisnis; (5) Fakultas Falsafah dan Peradaban; serta (6) Fakultas Ilmu Kesehatan.

Program studi Diploma III dikembangkan sebagai wahana penyiapan tenaga-tenaga terampil dalam keahlian praktis untuk memenuhi kebutuhan aktual masyarakat, khususnya dunia usaha. Pogram studi ini membuka sejumlah "jurusan” seperti: (1) Teknologi Informatika; (2) Disain; (3) Multimedia; (4) Teknologi Budidaya Pertanian; (5) Pengembangan Masyarakat; (6) Bisnis dan Keuangan; serta (7) Pelayanan Kesehatan.

Sementara itu, untuk pengembangan jaringan internasional, Universitas Paramadina Mulya menjalin hubungan kerjasama dengan berbagai universitas yang memiliki akreditasi internasional. Pada tahap awal, Universitas Paramadina Mulya telah membuat MoU (Memorandum of Understanding) dengan Curtin University of Technology, Perth, Australia. Rintisan kerjasama juga telah dilakukan dengan Emory University, Atlanta, Amerika Serikat; Georgetown University, Washington D.C., Amerika Serikat, Deakin University dan Melbourn University, Australia. Juga akan dirintis kerjasama dengan Muhammad ibn Su'ud Islamic University, Riyad, Saudi Arabia; Ain Shams University, Mesir; Middle East Technical University, Turki, dan lain-lain. ${ }^{42}$

Bagi Universitas Paramadina Mulya, gagasan mendirikan sebuah universitas, memang bukanlah suatu hal yang istimewa di negeri kita. Di pelbagai pelosok di wilayah negeri kita, banyak kita saksikan berdirinya universitas dengan berbagai corak ragam dan statusnya. Semuanya mencoba memberi jasa kepada bangsa dan negara,

${ }^{42}$ Ibid., 15. 
khususnya di bidang pembangunan dan pengembangan sumber daya manusia. Sebuah negeri dengan wilayah yang sedemikian luas, dan sebuah masyarakat dengan jumlah warga yang sedemikian banyak, tentu memerlukan perhatian dan kerja ekstra untuk membangun dan mengembangkannya. Semuanya itu harus dilakukan sehingga sebanding dengan kedudukan negara kita, Republik Indonesia, sebagai negara keempat terbesar di muka bumi. Karena itu, tak berlebihan jika dikatakan bahwa kehadiran Universitas Paramadina Mulya tidak saja memperlihatkan bangkitnya satu kesadaran 'baru' kalangan intelektual Islam di tanah air untuk menjangkau masa depan bangsanya, tetapi sekaligus berupaya memberi sumbangan kepada usaha perbaikan model pendidikan, sembari melihat kemungkinan melahirkan "model alternatif."

\section{Catatan Akhir}

Refleksi dan catatan singkat sekitar Paramadina dan kiprahnya di tengah-tengah kegairahan intelektualisme Islam di tanah air. Meskipun demikian, refleksi ini tidak dengan sendirinya dapat diklaim sebagai cerminan dari seluruh kecenderungan yang bergulir dalam dinamika yayasan ini. Tentunya masih banyak hal-hal lain yang belum sempat penulis kemukakan, terutama sekali karena keterbatasan ruang dan kurangnya waktu penulis dalam menelusuri kehidupan yayasan ini secara lebih rinci.

Kendati demikian, satu hal yang pasti-tentunya dengan mempertimbangkan sejumlah kekuatan dan kelemahannyakehadiran Paramadina dan pengembangan sayapnya di kemudian hari dalam bentuk Universitas Paramadina Mulya, sedikit banyaknya telah memberi kontribusi penting dalam gelombang intelektualisme Islam di Indonesia, terutama sekali getarannya sangat kuat terasa di kalangan masyarakat Islam urban, khususnya di Jakarta. Sebab, kehadiran Paramadina, sadar ataupun tidak, telah memberi ruang gerak cukup luas dalam menumbuhkan iklim intelektual yang berani, bebas, dialogis, toleran dan demokratis. Dari perspektif ini dapat dikatakan jika Paramadina lebih merupakan manifestasi paling konkret-kendati merupakan "miniatur" dari-obsesi "pembaruan pemikiran Islam" yang diembuskan Cak Nur dan kawan-kawannya sejak dekade awal 1970-an. 


\section{Daftar Rujukan}

Abdurrahman, Moeslim. "Bagaimana Indonesia Dibaca Pemikir Islam: Sebuah Resensi Pemikiran," dalam Muntaha Azhari dan Abdul Muni Saleh (eds.), Indonesia Menatap Masa Depan. Jakarta: Guna Aksara, 1989.

Ali, Fachry dan Effendy, Bahtiar. Merambah Jalan Baru Islam: Rekonstruksi Pemikiran Islam Indonesia Masa Orde Baru. Bandung: Mizan, 1986.

Ali, Fachry. "Akomodasi Non-Politik Islam Indonesia dalam Struktur Orde Baru," Prisma, No. 3 Tahun XX, Maret 1991.

Anwar, M. Syafi'i. "Negara, Masyarakat dan Artikulasi Politik Islam dalam Orde Baru," Republika, 14-15 April 1993.

Anwar, M. Syafi'i. "Sosiologi Pembaruan Pemikiran Islam Nurcholish Madjid" Ulumul Qur'an, Vol. 4, No. 1, 1993.

Anwar, M. Syafi'i. Pemikiran dan Aksi Islam Indonesia: Sebuah Kajian Politik tentang Cendekiawan Muslim Orde Baru. Jakarta: Paramadina, 1995.

Barton, Gregory J. "The Emergence of Neo-Modernism; a Progressive, Liberal, Movement of Islamic Thought in Indonesia: A Textual Study Examining the Writing of Nurcholish Madjid, Djohan Effendi, Ahmad Wahib and Abdurrahman Wahid 19681980". Disertasi--Department of Asian Languages and Studies Monash University, 1995.

Boland, B.J. "Discussion on Islam in Indonesia Today," Studies in Islam: A Symposium on Islamic Studies, Amsterdam, 18-19 Oktober 1973. Amsterdam: North Holland Publishing Company, 1974.

Boland, B.J. The Struggle of Islam in Modern Indonesia. The Hague: Martinus Nijhoff, 1982.

Hidayat, Komaruddin. "Studi Islam di Paramadina" dalam M. Dawam Rahardjo (ed.) Tragedi Raja Midas: Moralitas Agama dan Krisis Modernisme. Jakarta: Paramdina, 1998.

Karim, M. Rusli. "Responsi Cendekiawan Muslim terhadap Tuntutan Masyarakat Modern di Indonesia," dalam M. Amin Rais (ed.), Islam di Indonesia: Suatu Ikbtiar Mengaca Diri. Jakarta: Rajawali, 1986.

Liddle, R. William. "Changing Political Culture: Three Indonesian Cases," kertas kerja pada Konferensi tentang Indonesia Modern, Flinders University, Adelaide, South Australia, September 1991. 
Madjid, Nurcholish. "Modernisasi ialah Rasionalisasi Bukan Westernisasi" dalam Islam Kemodernan dan Keindonesiaan. Bandung: Mizan, 1987.

Mahasin, Aswab. "Marhaban”, Prisma, No. Ekstra, 1984.

Munawar-Rachman, Budhy (ed.). Kontekstualisasi Doktrin Islam dalam Sejarah. Jakarta: Paramadina, 1994.

Munawar-Rachman, Budhy "Berbagai Respon atas Gagasan Pembaruan," Ulumul Qur'an, Vol. 4, No. 1, 1993.

Munawar-Rachman, Budhy "Dari Tahapan Moral ke Periode Sejarah Pemikiran Neo-Modernisme Islam di Indonesia," Ulumul Qur'an, Vol. 6, No. 3, 1995.

Ramage, Douglas Edward. "Ideological Discourse in the Indonesian New Order: State Ideology and the Belief of an Elite, 1985-1993". Disertasi--International Studies, Department of Government and International Studies, University of South California, 1993.

Rasjidi. Pergolakan Pemikiran Islam: Catatan Harian Abmad Wabib. Jakarta: LP3ES, 1985.

Rasjidi. Sekularisme dalam Persoalan Lagi: Suatu Koreksi atas Tulisan Drs. Nurcholish Madjid. Jakarta: Yayasan Bangkit, 1972.

Rasjidi. Suatu Koreksi Lagi bagi Drs. Nurcholish Madjid. Jakarta: DDII, 1973.

Sjamsuddin, M. Sirajuddin. "Religion and Politics in Islam: the Case of Muhammadiyah in Indonesia's New Order". Disertasi-University of California Los Angeles, 1991.

Tampi, Nico J. "Trend Bacaan 1980-an: Cermin Meningkatnya Telaah Keagamaan," Diskusi Buku Agama, Bagian Perpustakaan dan Dokumentasi Majalah Tempo, Jakarta, 1987. 